Dunbar, and diseussed its affinities and systematic position, which he regarded as being among the Macrurous Decapods, although the absenee of the eyes in the preserved specimens, and some other characters, rendered it doubtful whether it might not in some respects approach the Stomapoda. Its position among the Macrura seemed, however, to be established by the well-developed abdominal somites and telson. He referred the fossil to Salter's genus Anthrapalamon, and named the species $A$. Woodwardi.

4. "On the Stratigraphical Position of the Corals of the Lias of the Midland and Western Counties of England and of South Wales." By R. F. Tomes, Esq. Communicated by R. Etheridge, Esq., F.R.S., V.P.G.S.

The object of this paper was to give the precise stratigraphical position of the species of Liassic Corals collected by the anthor and his friends in the districts above mentioned. He noticed 41 species, of which 15 were described as new, namely:-Cyclolites Anningi, Thecosmilia longiserialis, Montlivaltia eyclolites, Thamnastraa Etheridgii, Thecocyathus mucronata, Montlivaltia papyracea, and several others to which no specific names are attached, chiefly belonging to the genus Isastroa.

\title{
COERESPONDEITCE.
}

THE ACTIVE VOLCANO OF OSHIMA.

Sin,- - It may interest some of your readers to learn that since my return to Tokei, Japan, I find, from a microscopic examination, the lava from the Island of Oshima appears to be an Augitic Andesite, containing some Sanadine, and on the whole resembling some of the Java rocks, which will make it very interesting. JoHn MrLne.

Impertal College of Engineering, Kogakurio, Tokei, Japan. Warch $24 t h, 1877$.

\section{EXPLORATION OF VICTORIA CAVE, SETTLE, YORKSHIRE.}

Sir,- - It was with great surprise that I read, in an abstract of the proceedings of the Geological Society of London, the following passage: "The President asked Prof. Boyd Dawkins whether the impression which prevailed in some quarters that there had been a want of care in the excavation of the Victoria Cave was well founded."

Having lived for a long time in the north of England, anci having paid several visits to the Cave, since Mr. Tiddeman has had the charge of it, I feel bound to state that I have always been struck with the great care shown in the excavation, and with the scrupulous accuracy with which the position of every article found was noted.

I am morally certain that there is no ground whatever for any imputation of carelessness; it would indeed be a gross injustice both to $\mathrm{Mr}$. Tiddeman, who has so generously sacrificed so much of his spare time to the work, and also to Mr. Jackson, the discoverer of the Cave.

J. R. DAK YNS.

"See "Account of a Visit to the Active Volcano of Oshima" in Geol. MaG. May, $187 \bar{i}$, p. 193. 